\title{
Response of single-cut fodder sorghum genotypes to fertility levels under rainfed conditions of Rajasthan
}

\section{RAVI SHANKER MEENA, DEVENDRA SINGH AND BHANWAR LAL JAT}

Received : 20.05.2017; Revised : 09.08.2017; Accepted : 23.08.2017

See end of the Paper for authors' affiliation

Correspondence to :

\section{RAVI SHANKER MEENA}

Department of Agriculture, Bhagwant University, AJMER (RAJASTHAN) INDIA

Email : ramtaram24@gmail. com
ABSTRACT : The objectives were to study the appropriate sorghum fodder variety for this zone, work out the optimum fertility level for test genotypes and to study the economically viable treatment. Soil of experimental field was calcareous in nature, medium in available nitrogen (272.00), phosphorus (21.69) and high in available potassium (284.60). The experiment consisted of 24 treatment combinations comprising four levels of fertility $(50,75,100$ and $125 \% \mathrm{RDF}$ ) and six varieties (SPV-2185, SPV-2191, CSV-21F, HC- 308, CSV-30F and PC-1080) laid out in Factorial Randomized Block Design and replicated thrice. The result showed that among the genotypes, SPV-2185 produced maximum plant height, DMA at 25, 50DAS and at harvest, stem girth and number of leaves plant ${ }^{-1}$ at harvest, green and dry fodder yield, crude protein, ether extract, crude fibre mineral ash content and TDN in fodder. This genotype also estimated significantly gross and net returns over rest of the genotypes. However, maximum HCN content at 25 and 50DAS, organic carbon, available $\mathrm{P}$ and $\mathrm{K}$ status in soil after harvest with variety SPV-2191. Genotype CSV-21F produced maximum nitrogen status in soil. An application of $125 \%$ RDF recorded maximum plant height, stem girth, number of leaves at harvest, dry matter accumulation at various growth stages, green fodder and dry fodder yield, crude protein, crude fibre, ether extract, mineral ash content, TDN, HCN at 25 and 50 DAS, available organic carbon nitrogen phosphorus and potassium in soil after harvest over lower doses in all the above parameters. Highest nitrogen free extract were obtained under $50 \%$ RDF while, the lowest being recorded fewer than $125 \%$ RDF. In case of gross return, net return and $\mathrm{B}: \mathrm{C}$ ratio with application of $125 \% \mathrm{RDF}$ recorded significantly higher over $50 \% \mathrm{RDF}, 75 \% \mathrm{RDF}$ and $100 \% \mathrm{RDF}$.

- KEY WORDS : DMA, TDN, HCN, SPV-2191, CSV-21F

- HOW TO CITE THIS PAPER : Meena, Ravi Shanker, Singh, Devendra and Jat, Bhanwar Lal (2017). Response of single-cut fodder sorghum genotypes to fertility levels under rainfed conditions of Rajasthan. Internat. J. Agric. Engg., 10(2) : 423-440, DOI: 10.15740/HAS/IJAE/10.2/423-440. 